Jurnal Independent Vol 5 No. 2

\title{
TINJAUAN YURIDIS SISTEM PEMILIHAN KEPALA DESA DI KABUPATEN LAMONGAN BERDASARKAN PERATURAN DAERAH KABUPATEN LAMONGAN NOMOR 3 TAHUN 2015 TENTANG DESA
}

\author{
Oleh \\ Munif Rochmawanto \\ Dosen Fakultas Hukum Universitas Islam Lamongan
}

\begin{abstract}
Abstrak
Dalam melaksanakan amanat Pasal 31 Undang-Undang Nomor 6 Tahun 2014 tentang Desa, Peraturan Pemerintah Nomor 43 Tahun 2014 tentang Peraturan Pelaksanaan Undang-Undang Nomor 6 Tahun 2014 tentang Desa, dan Pasal 49 Peraturan Menteri Dalam Negeri Nomor 112 Tahun 2014 tentang Pemilihan Kepala Desa, maka perlu diatur kebijakan Pemerintahan Kabupaten/Kota dalam pelaksanaan pemilihan Kepala Desa yang dituangkan dalam suatu Peraturan Daerah sebagai payung hukum pelaksanaan pemilihan kepala desa. Peraturan Daerah Kabupaten Lamongan Nomor 3 Tahun 2015 tentang Desa tentunya harus disusun dengan tidak sekedar mengakomodir peraturan perundang-undangan diatasnya yang telah memberikan pengaturan secara umum, tetapi juga merinci kebutuhan penyelesaian masalah yang dapat muncul akibat pelaksanaan pemilihan kepala desa tersebut. Selain itu eksistensi Peraturan Desa setelah disahkanya Undang-Undang Nomor 6 Tahun 2014 tentang Desa bukan lagi berkedudukan sebagai penjabaran lebih lanjut dari peraturan perundangundangan yang lebih tinggi, melainkan telah berkedudukan sebagai peraturan perundangundangan yang diakui. Menurut Undang-Undang Nomor 12 tahun 2011 Tentang Pembentukan Peraturan Perundang-undangan yang menghilangkan peraturan desa dari hierarki, secara tidak langsung menghilangkan eksistensi Peraturan Desa dalam pelaksanaan pemilihan kepala desa.
\end{abstract}

Kata Kunci :Tinjauan Yuridis, Sistem Pemilihan Kepala Desa, Peraturan Daerah.

\section{PENDAHULUAN}

\section{Latar Belakang Masalah}

Pasal 1 ayat (1) Undang-Undang

Dasar Tahun 1945 (Selanjutnya disebut UUD 1945) menyatakan bahwa Negara Indonesia adalah Negara Kesatuan berbentuk Republik.

Dengan demikian, adanya daerah yang mempunyai kewenangan untuk mengatur dan mengurus rumah tangga sendiri harus diletakkan dalam kerangka negara kesatuan bukan negara federasi. Pasal 18 Undang-Undang Dasar 1945 sekaligus juga menegaskan bahwa Negara kesatuan repubik Indonesia merupakan suatu Negara kesatuan dengan system pemerintahan daerah yang bersifat desentralisasi. Dengan adanya ketentuan pasal 18 Undang-Undang Dasar 1945 tersebut semakin meneguhkan bahwa system pemerintahan daerah Indonesia mengadopsi prinsip Otonomi dan Desentralisasi

Pemerintahan Desa secara yuridis (hukum positif, ius constitutum) terdiri atas Kepala Desa dan Badan Permusyawaratan Desa, kedua institusi pemerintahan desa ini secara bersamasama dalam melakukan tugas dan kewenangan dalam hal pembangunan desa. Undang Undang Republik Indonesia No 6 Tahun 2014 menjelaskan bahwasannya Kepala Desa dipilih langsung oleh Penduduk Desa yang pada hari pemungutan suara Pemilihan Kepala Desa sudah berumur tujuh belas tahun atau sudah/pernah menikah ditetapkan sebagai pemilih. Sedangkan dalam Peraturan 
daerah Kabupaten lamongan Nomor 3 tahun 2015 lebih dijelaskan bahwasannya yang bisa memilih dalam Pemilihan Kepala Desa adalah Warga Desa yang bersangkutan yang memenuhi syarat dan ditetapkan dalam Daftar Pemilih Tetap, sedangkan yang dimaksud Daftar Pemilih Tetap disini adalah Daftar Pemilih Sementara dan Daftar Pemilih Tambahan yang ditetapkan oleh Panitia Pemilihan.

\section{METODE PENELITIAN Tipe Penelitian}

Tipe penelitian hukum yang saya lakukan adalah yuridis normatif. metode penelitian hukum normatif adalah suatu prosedur penelitian ilmiah untuk menemukan kebenaran berdasarkan logika keilmuan hukum dari sisi normatifnya. dan literatur-literatur yang ada kaitannya dengan permasalahan yang diteliti.

Oleh karena itu penelitian hukum ini difokuskan untuk mengkaji penelitian hukum tentang kaidah-kaidah atau normanorma dalam hukum positif, yakni norma hukum yang terkait dengan pelaksanaan Sistem Pemilihan Kepala Desa di Kabuapten Lamongan berdasarkan Peraturan Daerah Kabupaten Lamongan

\section{Pendekatan Masalah}

Oleh karena tipe penelitian yang digunakan adalah tipe penelitian yuridis normatif, maka pendekatan yang digunakan adalah pendekatan perundangundangan (statue approach). Pendekatan perundang-undangan adalah pendekatan yang dilakukan oleh peneliti melalui aturan perundang-undangan yang berkaitan dengan materi yang dibahas. Selain itu juga digunakan pendekatan konsep (conseptual approach) berkaitan dengan isu yang dihadapi. Pendekatan konsep digunakan untuk melihat permasalahan yang tekait dengan Tinjauan Yuridis Tentang Sistem Pemilihan Kepala Desa di Kabuapten Lamongan berdasarkan Peraturan Daerah Kabupaten Lamongan nomor 3 tahun 2014 tentang Desa.

\section{Bahan Hukum}

Dalam penulisan skripsi ini penulis menggunakan bahan-bahan hukum yang meliputi :

a) Bahan Hukum Primer adalah bahan hukum yang sifatnya mengikat berupa peraturan perundang-undangan yang berlaku dan ada kaitannya dengan permasalahan yang dibahas, meliputi :

1) Undang-undang Dasar 1945

2) Undang-Undang Nomor 12 tahun 2011 Tentang Pembentukan Peraturan Perundang-undangan

3) Undang-Undang Nomor 23 Tahun 2014 Tentang Pemerintahan Daerah

4) Undang-Undang Nomor 6 Tahun 2014 tentang Desa.

5) Peraturan Pemerintah Nomer 43 Tahun 2014 tentang Peraturan Pelaksanaan Undang-undang Desa

6) Peraturan Menteri Dalam Negeri Nomor 30 Tahun 2006 Tentang Tatacara Penyerahan Urusan Pemerintahan Kabupaten/Kota Kepada Desa

7) Peraturan Daerah Kabupaten Lamongan Nomor 3 Tahun 2015 tentang Desa

b) Bahan Hukum Sekunder adalah bahan yang diperoleh dari buku teks, jurnaljurnal, pendapat para sarjana dan kasuskasus hukum" bahan hukum yang sifatnya menjelaskan bahan hukum primer, dimana bahan hukum sekunder berupa buku literatur, hasil karya sarjana. Literatur tersebut antara lain :

1.) Buku-buku tentang Penelitian Hukum Normatif

2.) Buku-buku tentang Permasalahan yang diteliti

3) Website-website tentang Permasalahan yang diteliti.

c) Bahan Hukum Tersier adalah merupakan bahan hukum sebagai pelengkap dari kedua bahan hukum sebelumnya, berupa :

1) Kamus Hukum

2) Kamus Besar Bahasa Indonesia 


\section{Prosedur Pengumpulan Bahan Hukum}

Baik bahan hukum primer maupun sekunder dikumpulkan berdasarkan topik permasalahan yang dirumuskan dan di klarifikasi menurut sumber untuk dikaji secara komprehensif.

\section{Pengolahan dan Analisis Bahan Hukum} Adapun bahan hukum yang diperoleh dalam penelitian adalah studi kepustakaan aturan perundang undangan yang penulis uraikan dan dihubungkan sedemikian rupa sehingga disajikan dalam penulisan yang lebih sistematis guna menjawab perumusan masalah yang dirumuskan dan dilakukan secara deduktif yakni menarik kesimpulan dari suatu permasalahan yang bersifat umum terhadap permasalahan kongkrit yang dihadapi.

\section{HASIL PENELITIAN DAN PEMBAHASAN}

\section{Sistem Pemilihan Kepala Desa Menurut Peraturan Daerah Kabupaten Lamongan Nomor 3 Tahun 2015 Tentang Desa}

Dalam melaksanakan amanat Pasal 31 Undang-Undang Nomor 6 Tahun 2014 tentang Desa, Peraturan Pemerintah Nomor 43 Tahun 2014 tentang Peraturan Pelaksanaan Undang-Undang Nomor 6 Tahun 2014 tentang Desa, dan Pasal 49 Peraturan Menteri Dalam Negeri Nomor 112 Tahun 2014 tentang Pemilihan Kepala Desa, maka perlu diatur kebijakan Pemerintahan Kabupaten/Kota dalam pelaksanaan pemilihan Kepala Desa secara serentak yang dituangkan dalam suatu Peraturan Daerah sebagai payung hukum pelaksanaan pemilihan kepala desa. Peraturan Daerah tentang pemilihan kepala desa tentunya harus disusun dengan tidak sekedar mengakomodir peraturan perundang-undangan diatasnya yang telah memberikan pengaturan secara umum, tetapi juga merinci kebutuhan penyelesaian masalah yang dapat muncul akibat pelaksanaan pemilihan kepala desa tersebut. Secara garis besar, permasalahan yang harus diatur solusinya dalam Peraturan Daerah Kabupaten Lamongan Nomor 3 Tahun 2015 tentang pemilihan Kepala Desa dapat dirinci sebagai berikut :

1. Waktu pelaksanaan pemilihan kepala desa apabila dilaksanakan secara serentak satu kali ataupun bergelombang. Pemilihan Kepala Desa secara serentak disini tentunya harus mempertimbangkan jumlah Desa dan kemampuan biaya pemilihan yang dibebankan pada Anggaran Pendapatan dan Belanja Daerah Kabupaten Kapuas sehingga dimungkinkan pelaksanaannya secara dilakukan secara serentak satu kali atau dapat bergelombang. Termasuk yang diatur didalamnya adalah Pemilihan kepala desa antar waktu melalui musyawarah desa

2. Persyaratan pemilih;

3. Persyaratan Calon Kepala Desa yang berasal dari Kepala Desa incumbent, Perangkat Desa, Badan Permusyawaratan Desa, dan Pegawai Negeri Sipil;

4. Penentuan syarat tambahan apabila jumlah bakal calon lebih dari 5 (lima) orang;

5. Pelaksanaan waktu kampanye;

6. Pelayanan pemilihan kepala desa bagi pemilih yang berkebutuhan khusus;

7. Mekanisme penentuan hasil pemilihan serta penetapan;

8. Penyelesaian sengketa; dan

9. Sumber pembiayaan pemilihan Kepala Desa.

Terlepas dari apa yang harus diatur seperti yang disebutkan diatas, Pemerintahan Kabupaten/Kota juga dapat mengatur secara lebih khusus lagi substansi lain yang tidak bertentangan dengan ketentuan Peraturan PerundangUndangan diatasnya.

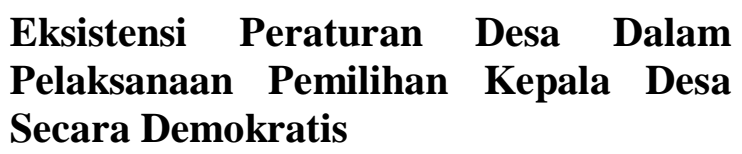


Berdasarkan Undang-Undang Nomor 6 Tahun 2014 tentang Desa yang berlaku saat ini, pemilihan kepala desa harus dilaksanakan secara serentak di seluruh wilayah kabupaten dan kota dengan ditetapkannya Peraturan Daerah untuk mengatur kebijakan dalam hal pemilihan kepala desa. Secara teknis yuridis, kata "dengan" harus ditafsirkan bahwa pengaturan mengenai pemilihan kepala desa harus dengan perda dan tidak dilimpahkan lagi ke bentuk peraturan lain. Berbeda dengan kata "berdasarkan" yang secara bebas pengaturannya dapat didelegasikan dengan peraturan lainnya. Akan tetapi dalam kenyataannya di beberapa daerah kabupaten dan sebagian kecil desa yang berada di kota tetap saja tidak mengatur secara tuntas pemilihan kepala desa di dalam peraturan desa, sehingga harus dijelaskan lagi dalam bentuk peraturan lainnya, misal Peraturan Bupati (Perbup). Kadang-kadang Perbupnya saling bertentangan dan semakin tidak jelas pengaturannya.

Peraturan Pemerintah Nomor 43

Tahun 2015 belum dilaksanakan secara sepenuhnya dilapangan, dikarenakan belum adanya penyusunan peraturan desa yang baru, lalu Peraturan Pemerintah Nomor 47 Tahun 2015 masih terbilang baru dan belum dipahami substansinya oleh Perangkat Desa pada saat itu. dan pada 31 Desember akhir 2014 Kementrian Dalam Negeri mengeluarkan peraturan no 111 tahun 2014 pedoman teknis peraturan di desa, jenis peraturan yang diatur di Permendagri 111 Tahun 2014 ini adalah tentang Peraturan Desa, Peraturan Bersama Kepala Desa, Peraturan Kepala Desa. Dalam Peraturan Daerah Kabupaten Lamongan Nomor 3 Tahun 2015 tentang Desa tidak satupun menyebutkan perihal peran Peraturan desa dalam pemilhan kepala desa. Dengan terbinya Peraturan Bupati no 42 tahun 2015 tentang pemilhan kepala desa kabupaten Lamongan sebagai pelaksanaan pasal 35 peraturan daerah kabupaten Lamongan nomor 3 tahun 2015 tentang desa.

\section{KESIMPULAN DAN SARAN Kesimpulan}

Dari uraian mengenai Tinjauan Yuridis Sistem Pemilihan Kepala Desa di Kabuapten Lamongan berdasarkan Peraturan Daerah Kabupaten Lamongan Nomor 3 Tahun 2015 Tentang Desa, maka dapatlah ditarik kesimpulan dari permasalahan- permasalahan yang terdapat dalam bab yang sebelumnya, maka dapat kesimpulan sebagai berikut :

1. Sistem pemilihan kepala desa menurut peraturan daerah kabupaten lamongan nomor 3 tahun 2015 tentang desa dan menurut peraturan bupati nomor 42 tahun 2015 tentang pemilihan kepala desa di kabupaten lamongan adalah melalui beberapa tahap:

a. Tahap persiapan, dalam tahap ini ditentukan syarat calon kepala desa.

b. Tahap pencalonan, dalam tahap ini menentukan kegiatan mulai pengumuman dan pendaftaran bakal calon sampai dengan kampanye.

c. Tahap pemungutan suara.

d. Tahap penetapan dan pengesahan calon terpilih serta pelantikan.

2. Eksistensi Peraturan Desa setelah disahkanya Undang-Undang Nomor 6 Tahun 2014 tentang Desa bukan lagi berkedudukan sebagai penjabaran lebih lanjut dari peraturan perundangundangan yang lebih tinggi, melainkan telah berkedudukan sebagai peraturan perundang-undangan yang diakui. Menurut Undang-Undang Nomor 12 tahun 2011 Tentang Pembentukan Peraturan Perundang-undangan yang menghilangkan peraturan desa dari hierarki, secara tidak langsung menghilangkan eksistensi Peraturan Desa dalam pelaksanaan pemilihan kepala desa.

\section{Saran}

Berdasarkan Setelah menganalisa data-data yang ada, maka saran penulis mengenai Tinjauan Yuridis Sistem Pemilihan Kepala Desa di Kabuapten Lamongan berdasarkan Peraturan Daerah 
Kabupaten Lamongan Nomor 3 Tahun 2015 Tentang Desa adalah sebagai berikut:

1. Pemilihan kepala desa di Indonesia sebaiknya benar-benar dihormati dan diperhatikan keberadaannya dalam negara dengan berbagai fasilitas terhadap seluruh kebutuhan yang dibutuhkan dalam pelaksanaannya. Tentunya tetap memperhatikan hakhak, asal-usul, dan adat istiadat desa setempat.

2. Agar pemilihan kepala desa menjadi lebih baik penulis menyarankan agar Bupati Lamongan hendaknya dapat mengeluarkan peraturan bupati sebagai pelaksanaam Peraturan Daerah Kabupaten Lamongan Nomor 3 Tahun 2015 tentang Desa Tentang Kepala Desa terutama pasal mengenai sanksi agar diatur dengan jelas dan tegas, sehingga setiap aturan yang dibuat bisa dijalankan dengan baik.

3. Undang-Undang Nomor 6 Tahun 2014 tentang Desa telah banyak memberikan kewenangan kepeda pemerintah daerah dalam hal penyelenggaraan pemerintahan desa. Secara khusus dalam hal penetapan peraturan desa. Untuk itu pemerintah seharusnya memberikan sosialisasi yang tepat dan benar secara khusus kepada kepala desa berkaitan tentang muatan Peraturan desa menurut Undang-Undang Nomor 6 Tahun 2014 tentang Desa.

\section{DAFTAR PUSTAKA}

\section{Literatur}

a. Departemen Pendidikan dan Kebudayaan, Kamus Besar Bahasa Indonesia, Balai Pustaka, Jakarta 1991,

b. Peter Mahmud Marzuki. Penelitian hukum. kencana. Jakarta. 2005.

c. Johnny ibrahim, teori dan metode penelitian hukum normatif, banyumedia publishing, malang. 2006 d. Rusdianto Sesung. Hukum Otonomi Daerah. Rafika Aditama. Bandung. 2013.

e. Almanak Desa. Kementerian Desa, Pembangunan Daerah Tertinggal, dan Transmigrasi Republik Indonesia. 2016

f. Kewenangan desa dan regulasi desa. Kementerian Desa, Pembangunan Daerah Tertinggal, dan Transmigrasi. 2015

g. Borni Kurniawan. Lebih Dekat dengan Kewenangan Desa. Infest. Jogjakarta.2016

h. Kepemimpinan Desa. Kementerian Desa, Pembangunan Daerah Tertinggal Dan Transmigrasi Republik Indonesia. Jakarta 2015

\section{Perundang-Undangan}

a. Undang-undang Dasar 1945

b. Undang-Undang Nomor 32 Tahun 2004 Tentang Pemerintahan Daerah

c. UU No. 6 Tahun 2014 tentang Pemerintahan Desa.

d. Peraturan Pemerintah Nomer 43 Tahun 2014 tentang Peraturan Pelaksanaan Undang-undang Desa

e. Peraturan Menteri Dalam Negeri Nomor 112 Tahun 2014 tentang Pemilihan Kepala Desa

f. Peraturan Daerah Kabupaten Lamongan Nomor 3 Tahun 2015 tentang Desa

\section{Sumber internet}
a. www.edukasippkn.com
b. http://pemerintah.net
c. https://kbbi.kemdikbud.go.id/
d. http://www.dictio.id
e. http://www.academia.edu 